\title{
RYNEK KINA ARTYSTYCZNEGO W NOWYM HOLLYWOOD
}

Zdaniem francuskiego filmowca Bertranda Taverniera w Stanach Zjednoczonych zagranicznym filmom przypada $\mathrm{w}$ udziale zaledwie 2 procent całego czasu ekranowego w kinach. „Trzyma się nas w rezerwatach niczym plemiona Cherokee i Navaho" - mówi twórca Około pótnocy (Round Midnight), filmowego hitu z roku 1986 prezentującego paryską scenę jazzową lat dwudziestych. „Nasze filmy pokazuje się tylko w kilku miejscach - Nowym Jorku, Los Angeles i jeszcze w paru większych miastach"

Dogorywający przez całą złotą erę Hollywood rynek kina artystycznego odrodził się w Stanach Zjednoczonych po II wojnie światowej, kiedy to do kraju napływać zaczęły kolejne fale rozlicznych kinematografii narodowych. Liczba kin, które regularnie wyświetlały filmy artystyczne (a więc filmy nieanglojęzyczne bądź też filmy anglojęzyczne, ale wyprodukowane za granicą bez finansowego wsparcia ze strony amerykańskiej) ${ }^{*}$, wzrosła z około stu w latach 50. do prawie siedmiuset $\mathrm{w}$ następnej dekadzie. Początkowo dystrybucją kina zagranicznego w Stanach Zjednoczonych zajmowały się dziesiątki niezależnych przedsiębiorstw, jednak po kasowym sukcesie filmu I Bóg stworzyt kobietę (Et Dieu... créa la femme, 1956) z Brigitte Bardot pieczę nad tym sektorem przejęło Hollywood. Przy okazji poszukiwań zagranicznych filmów z komercyjnym potencjałem, wielkie wytwórnie (majors) pozyskały sobie najbardziej utalentowanych filmowców zagranicznych, oferując im pomoc finansową w produkcji filmów, a także ich dystrybucji na lukratywnym rynku amerykańskim.

To właśnie za sprawą Hollywood amerykańska kultura filmowa lat 60. stała się bogatsza o dzieła najbardziej znanych autorów filmowych, takich jak Federico Fellini, Ingmar Bergman, Akira Kurosawa, Michelangelo Antonioni, François Truffault, Alain Resnais, Bernardo Bertolucci czy Tony Richardson. Ale złote czasy kina artystycznego za Oceanem trwały bardzo krótko. Upadek kodeksu produkcyjnego, liberalne orzeczenia Sądu Najwyższego odnośnie do cenzury, a także głębokie zmiany w obyczajowości społeczeństwa amerykańskiego - wszystkie te okoliczności doprowadziły do wyłonienia się około roku 1967 nadspodziewanie brak daty.

1 S. Valongo, American Filmgoers Criticized, „The Toledo Blade”, wycinek prasowy, 
bezpośredniego kina amerykańskiego, a tym samym do, jak ujęto w branżowym czasopiśmie „Variety”, „osłabienia tego, co kiedyś stanowiło rynek kina artystycznego"2. Wielkie wytwórnie obcięły wydatki na zagraniczne produkcje oraz zamknęły jednostki dystrybucyjne zajmujące się kinem artystycznym, w efekcie czego zagranicznym filmom było trudniej niż kiedykolwiek wkroczyć na rynek amerykański.

W artykule tym wykażę, że po roku 1970 rynek kina artystycznego w USA funkcjonował na zasadzie biznesowej niszy i opierał się głównie na nieanglojęzycznych oraz anglojęzycznych filmach wyprodukowanych za granicą bez żadnego wsparcia ze strony amerykańskiej ${ }^{3}$. Rynek ten był domeną dystrybutorów niezależnych oraz tzw. mini-majors ${ }^{* *}$, takich jak Orion Pictures czy Dino De Laurentis Entertainment, których działalność dowiodła, że filmy niszowe ${ }^{* * *}$, jeżeli tylko są właściwie rozpowszechniane, mogą od czasu do czasu zgromadzić dość liczną widownię kinową, a także przynieść zyski na rynkach uzupełniających (ancillary markets), w szczególności zaś na formującym się od początku lat 80. rynku VHS. Biznesowy potencjał kina artystycznego był jednak niewielki, stąd też na powierzchni utrzymały się wyłącznie najbardziej odporne firmy. Gdy w latach 90. doszło do konsolidacji amerykańskiego przemysłu filmowego, kontrolę nad rynkiem kina artystycznego przejęly wielkie wytwórnie hollywoodzkie, które bądź to same tworzyły wyspecjalizowane oddziały (classics divisions), bądź też wchłaniały czołowych, niezależnych dystrybutorów kina artystycznego. Choć takie posunięcia przywodziły na myśl politykę wielkich studiów z lat 60 ., ponowne zainteresowanie filmem artystycznym nie pociągnęło za sobą finansowego zaangażowania Nowego Hollywood w produkcję filmów zagranicznych. Natomiast podobnie jak w latach 60. Hollywood pozyskało sobie wielu obiecujących filmowców zagranicznych, pozbawiając w ten sposób „inne kinematografie narodowe ich najbardziej utalentowanych twórców i tym samym osłabiając potencjalną konkurencję dla własnych produktów" .

\section{Okrojony rynek filmu artystycznego}

Dane, jakie podaje „Variety”, różnią się nieco od tych przywołanych przez Taverniera na wstępie artykułu. Według branżowego czasopisma obcojęzycznym oraz anglojęzycznym filmom $\mathrm{z}$ importu (imports) przypada w udziale od 1 do

2 A. Verrill, Hard Going in U.S. for Foreign Films, „Variety” 1972, 3 May, s. 31.

3 W latach 80. rynek kina artystycznego zaczął obejmować także niezależne produkcje amerykańskie powstałe poza Hollywood. Ponieważ większość z tych filmów skierowana była do młodzieży, natomiast ich dystrybucja bazowała głównie na rynku wideo oraz płatnej telewizji kablowej, w artykule tym skoncentrowano się na zagranicznych filmach $\mathrm{z}$ importu.

4 J. Hiller, The New Hollywood, Continuum: New York 1994, s. 163. 
9 procent wpływów kasowych w USA, co oznacza, że corocznie uzyskują one średnio około 5 procent ${ }^{5}$. Przy czym każdego roku w tej grupie filmów zdarzają się jeden lub dwa hity, które zgarniają większą część puli. Bardzo długo najbardziej dochodowym filmem obcojęzycznym na rynku amerykańskim był obraz Jestem ciekawa w kolorze żóttym (Jag är nyfiken - en film i gult) Vilgota Sjömana, który w roku 1969 zarobił w kinach 19 milionów dolarów. Rekord ten pobił dopiero film Przepiórki w płatkach róży (Como agua para chocolate) Alfonsa Araua, osiągając w roku 1993 wpływy na poziomie 20 milionów dolarów. Spośród pozostałych obcojęzycznych hitów kinowych wymienić należy filmy: Klatka szaleńców (La Cage aux folles) Eduarda Molinara (17 milionów dolarów w roku 1979), Okręt (Das Boot) Wolfganga Petersena (11,2 miliona dolarów w roku 1982), Kobiety na skraju załamania nerwowego (Mujeres al borde de un ataque de nervios) Pedra Almodòvara (7,5 miliona dolarów w roku 1988) oraz Cinema Paradiso Giuseppe Tornatorego (13 milionów dolarów w roku 1990 ${ }^{* * * *}$.

Anglojęzyczne filmy z importu radzily sobie zdecydowanie lepiej. Ostatnie tango w Paryżu (Last Tango in Paris) Bernarda Bertolucciego zarobilo w roku 1973 ponad 40 milionów dolarów, Rydwany ognia (Chariots of Fire) Hugh Hudsona 62 miliony dolarów w roku 1981, Ghandi Richarda Attenborough 52 miliony dolarów w roku 1982 i w końcu Ostatni cesarz (The Last Emperor) Bertolucciego 43,5 miliona dolarów w roku 1987. Jednakże wymienione tu obrazy trudno uznać za typowe filmy z importu, ponieważ były one albo amerykańskimi koprodukcjami, albo amerykańskimi filmami wyprodukowanymi przez zagraniczne firmy producenckie, albo zagranicznymi filmami zrealizowanymi przy amerykańskim wsparciu finansowym.

Jeżeli chodzi o zapotrzebowanie na filmy artystyczne, czy to obcojęzyczne, czy też anglojęzyczne, to od lat 70 . zmieniło się w tym względzie niewiele. „W przemyśle filmowym, gdzie operuje się dziesiątkami milionów dolarów”, jak czytamy w magazynie „Premiere”, „dystrybucja i marketing niskobudżetowych, niezależnych filmów amerykańskich oraz zagranicznych filmów artystycznych to małe ziemniaczki, które stanowią dodatek do pieczystego"'. Aby uzyskać status najbardziej dochodowego filmu obcojęzycznego na rynku amerykańskim, rozpowszechniany przez Miramax obraz Przepiórki w płatkach róży wyświetlany musiał być w kinach przez ponad rok, podczas gdy Forrest Gump potrzebował zaledwie czterech dni by pobić ten rekord ${ }^{7}$. Liczba kin, w których w dniu swej premiery wyświetlany jest film wypuszczony przez jedną z wielkich wytwórni, waha się zwykle pomiędzy tysiącem pięćset a trzema tysiącami. Tymczasem nawet najbardziej obiecujący film artystyczny rzadko może liczyć

5 Alien Ration, „Variety” 1991, 21 October, s. 8.

6 Indie Boom Turns Bust, „Premiere” 1989, May, s. 31.

7 L. Klady, H'wood Foreign Rub, „Variety” 1994, 12-18 September, s. 9. 
na otwarcie w więcej niż stu kinach. Filmy artystyczne muszą być jednak dystrybuowane powoli, ponieważ ich głównym sprzymierzeńcem są pozytywne opinie widzów oraz entuzjastyczne recenzje krytyki. Te zaś potrzebują sporo czasu, aby się rozprzestrzenić. Jako że rynek filmowy jest niezwykle zmienny i nieprzewidywalny, za kinowy hit uznaje się każdy film zagraniczny, któremu w USA udało się osiągnąć wpływy na poziomie 5 milionów dolarów. Natomiast zagraniczny producent może się mieć za wyjątkowego szczęściarza, jeżeli za prawa do rozpowszechniania swojego filmu otrzyma od amerykańskiego dystrybutora 500 tysięcy dolarów zaliczki ${ }^{8}$.

Oscar dla najlepszego filmu obcojęzycznego dodaje zwycięzcy prestiżu i przekłada się na dłuższy okres rozpowszechniania, a także większe wpływy w kasach. Biorąc pod lupę sumy uzyskane przez laureatów Oscara z lat 1986-1993, redaktorzy „Variety” wykazali, że po otrzymaniu nagrody w przypadku niektórych filmów wpływy z kas kinowych wzrosły nawet 2000 procent. Przy czym, liczone w dolarach, wpływy te wahały się pomiędzy 260 tysiącami dolarów dla szwedzkiego zwycięzcy z roku 1991, Podróż nadziei (Reise der Hoffnung) Xaviera Collera, a 13 milionami dolarów dla włoskiego triumfatora gali z roku 1989, Cinema Paradiso. W poddanym badaniom okresie pięciu $\mathrm{z}$ ośmiu laureatów Oscara zarobiło w kinach mniej niż 5 milionów dolarów ${ }^{9}$. Warto w tym miejscu ponownie powołać się na „Variety”:

Większość dystrybutorów europejskiego kina artystycznego nie uznaje Oscara za czynnik przesądzający o kasowym sukcesie filmu. Bardzo wielu kierowników wykonawczych wierzy, że widzów do kin przyciągną walory filmu, dlatego też rozpowszechniają go na szeroką skalę na długo zanim Akademia ogłosi swój werdykt. A jeśli film od razu ponosi klęskę, to wtedy nawet Oscar nie jest w stanie go uratować ${ }^{10}$.

Zagraniczne filmy już na samym wstępie napotykają na poważne trudności. Wrota do rynku kina artystycznego otwiera Nowy Jork. W mieście tym znajduje się większość redakcji ogólnokrajowych gazet i czasopism, zamieszkuje w nim także spora część wielbicieli kina artystycznego. Jednak, jak czytamy w „New York Times”, „Nowy Jork jest jednocześnie wspaniałym snem i koszmarem”. Koszty reklamy są tu wygórowane, a choć dobre recenzje mają ogromny wpływ na sukces filmu w wymiarze ogólnokrajowym, złe recenzje albo też nieprzychylna notatka w „New York Times” z miejsca mogą pogrzebać nadzieje na dobry wynik. Poza Nowym Jorkiem nie jest lepiej. Film bez znanego reżysera albo rozpoznawalnych gwiazd ma małe szanse, by przyciągnąć uwagę mediów. Dystrybutorzy narzekają,

8 D. Young, Figuring Out the Arthouse Market, „Variety” 1992, 18 May, s. 3, 85.

9 L. Klady, When Oscar Talks, the B.O. Listens, „Variety” 1994, 4-10 April, s. 7.

10 D. Elley, Win Helps, but Won't Make Pic in Europe, „Variety” 1993, 4 January, s. 62. 
że „nawet gazety w dużych miastach ignorują filmy artystyczne, dając się uwieść czarowi i wielkim pieniądzom Hollywood. Rzeczą wręcz niemożliwą, jak mówią, jest zwabienie krytyków na pokazy do kina"11.

Ale nawet przy życzliwym nastawieniu mediów, zagraniczne filmy mają problemy z dotarciem do widzów. Na poziomie eksploatacji czynnikiem hamującym jest fakt likwidacji w latach 80 . dużej liczby wyspecjalizowanych kin, których właściciele złożyli broń w obliczu presji agencji handlu nieruchomościami, rozwoju rynku wideo oraz trendu do przekształcania przez ogromne sieci kinowe jednoekranowych kin artystycznych w bardziej dochodowe multipleksy wyświetlające hollywoodzką papkę. Dla przykładu, w Nowym Jorku zamknięto bądź też przekształcono w kina premierowe takie przybytki filmu artystycznego jak Cinema Studio w pobliżu Lincoln Center, Embassy, Regency, Metro, Thalia czy też kina New Yorker na Upper West Side. W Bostonie, „opoce obiegu kina artystycznego", prawie wszystkie niezależne kina przejęte zostały przez wielkie hollywoodzkie firmy ${ }^{12}$. Wyjątek od tej reguly stanowi licząca sobie sto dwadzieścia pięć ekranów sieć kin Landmark, będąca własnością Samuel Goldwyn Co., która jako jedyna w ostatnich latach prezentuje wyłącznie kino artystyczne $e^{13}$.

Na poziomie dystrybucji w latach 80 . powstało co prawda wiele firm zajmujących się rozpowszechnianiem zagranicznych filmów oraz niezależnego kina amerykańskiego, które czerpały latwe pieniądze z przedsprzedaży praw dla wydawców kaset wideo oraz telewizji kablowych. Pod koniec dekady doszło jednak do poważnego załamania rynku, który okazał się przesycony dużą liczbą filmów wątpliwej jakości. W konsekwencji dziesiątki firm dystrybucyjnych zbankrutowało bądź też popadło w ruinę. Na liście ofiar znalazły się Aries, New World Pictures, New Century, Cinecom, Island Alive, Orion, Atlantic, Avenue, Hemdale, Cannon, Lorimar oraz De Laurentis. Większość z nich przynajmniej okazjonalnie zajmowała się dystrybucją filmów zagranicznych.

Szczególnym zawodem był przypadek Orion Pictures. Oddział kina artystycznego tej firmy, Orion Classics, był jednym z najbardziej agresywnych graczy na rynku. Dzięki stałej praktyce nabywania filmów na wyłączność już na etapie preprodukcji i płacenia za nie dużych sum pieniędzy, zapewnił sobie prawa dystrybucyjne do takich obrazów jak Kobiety na skraju załamania nerwowego Pedra Almodòvara, Europa, Europa (1991) Agnieszki Holland, który został nagrodzony Złotym Globem dla najlepszego filmu zagranicznego i przyniósł

11 W. Grimes, Diffrent Rules, Diffrent Rewards for Smaller Films, „New York Times” 1992, 31 June, s. B1, B7.

12 Indie Boom...

13 A. Harmetz, Sam Goldwyn's Little Studio that Could, „New York Times” 1992, 18 October, s. 23. 
zyski w wysokości 5,6 miliona dolarów, a także najbardziej dochodowej produkcji z Chin, Zawieście czerwone latarnie (Da hong deng long gao gao gua, 1991) Zhanga Yimou'14.

\section{Ocaleni}

Lata 80. przetrwała tylko garstka najsilniejszych: Miramax, Fine Line oraz Samuel Goldwyn Co. Miramax, najlepiej prosperująca z tych trzech firm, wyrobiła sobie „markę, która przyciągała widzów do kin bez względu na film”. Założona w roku 1982 przez Harveya i Boba Weinsteinów firma Miramax awansowała do pierwszej ligi niezależnych dystrybutorów dopiero w roku 1989, kiedy to trzy rozpowszechniane przez nią filmy przyciągnęły uwagę krytyki i widzów: Moja lewa stopa (My Left Foot) Jima Sheridana, w którym główną rolę zagrał wciąż jeszcze mało znany Daniel Day-Lewis (za tę kreację otrzymał później Oscara dla najlepszego aktora) i który w kinach zarobił 14,7 miliona dolarów; Seks, kłamstwa $i$ kasety wideo (Sex, lies and videotape) Stevena Soderbergha, który dał reżyserowi (a zarazem scenarzyście) Złotą Palmę w Cannes i przyniósł wpływy w wysokości 24,7 miliona dolarów; i w końcu Cinema Paradiso Giuseppego Tornatorego, który zdobył Oscara dla najlepszego filmu zagranicznego i okazał się być najbardziej dochodowym filmem artystycznym roku $1990^{15}$.

Miramax od samego początku przyjęło strategię zakupu filmów na wyłączność. W latach 90. na ekrany kin wprowadzało corocznie ponad tuzin niezwykle różnorodnych obrazów, zyskując sobie przy okazji o wiele większe uznanie Akademii Filmowej aniżeli inne czołowe firmy. O sukcesie Miramax przesądziły w głównej mierze zdolności marketingowe jej pracowników. "Jesteśmy firmą dystrybucyjną bazującą na reklamie oraz poczcie pantoflowej", mówił kierownik wykonawczy ${ }^{16}$.

O umiejętności pozyskiwania przez braci Weinsteinów darmowej reklamy krążą legendy. $\mathrm{Z}$ reguły firma nabywała filmy na festiwalach. Cała strategia sprowadzała się do tego, by wychwycić film mający największe szanse na wygraną, a następnie wykorzystać do celów dystrybucyjnych prasowy szum wokół jego festiwalowego sukcesu. Za dobry przykład posłużyć może Fortepian (The Piano, 1993) w reżyserii Jane Campion. Ten kulturowy koktajl sfinansowany przez francuską firmę CIBY 2000, zrealizowany w Nowej Zelandii przez rodzimą scenarzystkę i reżyserkę przy wsparciu międzynarodowej obsady, a na dodatek posiadający akcent australijski w osobie producenta Jana Chapmana, Miramax zakupiło na

14 L. Cohn, „Mediterraneo”, 92's Most Moneyed Import, „Variety” 1993, 11 January, s. 5, 63; P. Bart, Oscar Snubs, „Variety” 1992, 3 February, s. 5.

15 J. E. Frook, Miramax Paradiso, „Variety” 1992, 21 September, s. 101, 106.

16 Ibidem. 
długo przed pokazem na festiwalu w Cannes, gdzie film zdobył ostatecznie Złotą Palmę ${ }^{17}$. Niedługo potem „Newsweek” poświęcił Fortepianowi dwustronicowy artykuł z jednym całostronicowym zdjęciem, opisując, na sześć miesięcy przed premierą filmu w USA, „entuzjastyczną owację na stojąco” po jego festiwalowej projekcji oraz „gorączkową reakcję" pierwszych odbiorców ${ }^{18}$.

Zakupione przez Miramax filmy często zostają przemontowane, aby stać się bardziej przystępne dla amerykańskiej publiczności. Z powodu tej kontrowersyjnej praktyki Harvey Weinstein zyskał sobie nawet miano „Harveya Nożycorękiego". Nie ulega jednak wątpliwości, że jego zamiłowanie do cięcia filmowej taśmy miało niemały udział w sukcesie trzech filmów: Cinema Paradiso; Żegnaj, moja konkubino (Ba wang bie ji, 1993) oraz Przepiórki w płatkach róży. Skrócenie tego ostatniego o 15 minut pomogło bardzo szybko odzyskać zainwestowane w niego 2,5 miliona dolarów, a następnie osiągnąć status najbardziej dochodowego filmu obcojęzycznego w historii amerykańskiej dystrybucji ${ }^{19}$.

Ulubioną sztuczką Miramax, służącą wzbudzeniu zainteresowania danym filmem, jest oprotestowanie kategorii wiekowej, przyznanej przez Motion Picture Association of America (MPAA). Ciekawego przykładu dostarcza w tym względzie Zwiąż mnie (Atame!, 1990) w reżyserii Pedra Almodòvara. Po tym jak MPAA opatrzyło film najbardziej restrykcyjną kategorią X, Miramax wynajęło wybitnego adwokata, aby zaskarżył tę decyzję. Prawnik argumentował, że erotyka w filmie Almodòvara jest niczym w porównaniu z bezpośredniością wielu hollywoodzkich obrazów, takich jak chociażby Blue Velvet (1986) Davida Lyncha, i że kategoria X może bardzo niekorzystnie wpłynąć na finansowy wynik całego przedsięwzięcia. Orzekając na korzyść MPAA, sąd stwierdził, że „zarzuty ekonomicznj dyskryminacji i narażania firmy na finansową szkodę są bezpodstawne, a wykorzystanie przez Miramax kategorii X w kampanii reklamowej... przemawia za tym, iż postępowanie sądowe pełni raczej funkcję promocji filmu”. Ostatecznie Miramax wypuściło Zwiąż mnie z pominięciem kategorii wiekowej. Jednak dzięki darmowej reklamie w postaci medialnego szumu wokół sądowej batalii, zarobiło na filmie ponad 3 miliony dolarów ${ }^{20}$. Weinsteinowie powtórzyli tę samą sztuczkę przy okazji premiery takich filmów jak Naciagacze (The Grifters, 1990), Rozróba w Harlemie (A Rage in Harlem, 1991), W łóżku z Madonna (Madonna: Truth or Dare, 1991) i wielu innych.

Prawdopodobnie najbardziej pomysłową kampanię reklamową Miramax zastosowało w przypadku promocji filmu Gra pozorów (The Crying Game, 1992)

17 D. Groves „Piano” Wins 11 Oz Film Honors, „Variety” 1993, 15 November, s. 11.

18 D. Ansen, Passion for Piano, „Newsweek” 1993, 31 May, s. 52-53.

19 B. Sharkey, The Brothers Miramax, „New York Times” 1994, 24 April, s. 1, 18, 19.

20 Excerpts from the Miramax vs. MPAA Ruling, „Los Angeles Times” 1990, 21 July, s. 7. 
w reżyserii Neila Jordana. Przekonanie widzów do tego, żeby zobaczyli film, nie wiedząc tak naprawdę, dlaczego chcą to zrobić, było nie lada wyczynem. $\mathrm{Na}$ pierwszy rzut oka ta pozbawiona gwiazd brytyjska opowieść o konflikcie pomiędzy Wielką Brytanią a IRA nie nadaje się do sprzedaży Amerykanom. Jednak film posiadał pewien atut: zaskakującą przewrotkę fabularną (twist). I to właśnie ona została wykorzystana przez Miramax w celu wytworzenia cause célèbre na miarę słynnej kampanii reklamowej Psychozy (Psycho, 1960) Alfreda Hitchcocka. Podczas prezentacji obrazu na nowojorskim festiwalu filmowym dziennikarzom wręczono list następującej treści: „Producenci oraz reżyser Gry pozorów uprzejmie proszą o to, by nie zdradzali Państwo głównych zwrotów akcji w fabule filmu”. Krytycy dostosowali się do tej instrukcji, a w ślad za nimi poszli także widzowie. Reklamowana jako „Najpilniej strzeżona tajemnica Ameryki”, Gra pozorów stała się wielkim hitem kinowym, zarabiając oszałamiającą sumę 62 milionów dolarów. Na dodatek film odniósł sukces artystyczny, otrzymując sześć nominacji do Oscara ( $w$ tym za najlepszy film), z których jedna zamieniła się w statuetkę za najlepszy scenariusz dla Neila Jordana ${ }^{21}$. Jak donosiło „Variety”: „Tak gorące przyjęcie filmu wstrząsnęło całym przemysłem filmowym"22.

Miramax znane jest $\mathrm{z}$ tego, że po wypuszczeniu filmu na rynek potrafi szybko reagować na każdą nadarzającą się okazję do zwiększenia zysków. Gdy pojawily się pierwsze recenzje Przepiórek w platkach róży, Miramax zdecydowało się wykroczyć poza krąg kin artystycznych i wprowadziło film do hiszpańskojęzycznych kin położonych w latynoamerykańskich dzielnicach. W trakcie eksploatacji filmu użyto w sumie 179 kopii $\mathrm{z}$ angielskimi napisami. I choć nie dawało to możliwości jednoczesnej projekcji w 500 kinach, tak jak w przypadku Gry pozorów, to i tak dystrybucyjny zasięg Przepiórek $w$ płatkach róży był bardzo duży jak na film obcojęzyczny ${ }^{23}$. Aby zwiększyć potencjał obrazu, Miramax bardzo dokładnie zaplanowało wielokierunkową kampanię reklamową, do której zaprzęgnięto Mexicana Airlines, meksykańskie restauracje i stacje radiowe, a także dodatki do gazet poświęcone turystyce, rozrywce, kulinariom oraz książkom. Te ostatnie miały promować napisaną przez żonę Alfonsa Araua, Laurę Esquivel, powieść, na podstawie której powstał film. Książka opublikowana przez wydawnictwo Doubleday przez dziewiętnaście miesięcy utrzymywała się na liście bestsellerów „New York Times” ${ }^{24}$.

Aby zneutralizować ryzyko związane z działalnością na rynku kina artystycznego, Miramax utworzyło w roku 1992 nową jednostkę dystrybucyjną Dimension

21 P. Stack, Secret of Crying Game Success, „San Francisco Chronicle” 1993, 23 February, s. $1+$. s. $1,68,69$.

22 M. Fleming, L. Klady, „Crying” All the Way to the Bank, „Variety” 1993, 22 March,

23 L. Cohn, „Like Water” Crossover a Spanish-lingo Record, „Variety” 1993, 21 June, s. 7.

24 S. Karlin, Sweet Shortcut for Hot „Chocolate”, „Variety” 1993, 30 August, s. 1. 
Pictures, zaangażowaną w rozpowszechnianie kina gatunków. „Variety” scharakteryzowało znajdujące się w jej ofercie filmy jako „obrazy sprawiające, że widzowie krzyczą i kupują więcej popcornu”2s. Jednym z pierwszych przedsięwzięć Dimension była seria horrorów, na którą składały się takie filmy jak Hellraiser III: Piekło na ziemi (Hellraiser 3: Hell on Earth, 1992) oraz Dzieci kukurydzy II: Ostateczne poświęcenie (Children of the Corn: The final Sacrifice, 1992). W przeciwienstwie do filmów artystycznych ten rodzaj kina świetnie nadawał się do sprzedaży wydawcom kaset wideo, telewizjom i dystrybutorom zagranicznym.

Wejście Miramax na rynek kina gatunków stanowiło odpowiedź na utworzenie w roku 1991 przez New Line Cinema oddziału Fine Line Features. Strategię założonej w roku 1967 przez absolwenta prawa na Columbia University, Roberta Shaye'a, firmy New Line najlepiej opisuje zdanie zawarte w jej biznesplanie: „tworzyć i dystrybuować niskobudżetowe, nieobciążone dużym ryzykiem filmy oraz starannie dobierać docelową publicznośćn" ${ }^{26}$. W pierwszych latach swej działalności New Line celowała przede wszystkim w kluby dyskusyjne na uniwersyteckich kampusach, jednak już w latach 70. rozszerzyła swą działalność na rynek kinowy, dystrybuując midnight movies (Różowe flamingi, 'Pink Flamingos', 1972, Johna Watersa), filmy erotyczne (The Best of the New York Erotic Film Festival), filmy kung-fu (Uliczny wojownik, 'Gekitotsu! Satsujin ken', 1974, z Sonnym Chibą), a także filmy artystyczne (Desperacja, 'Despair', 1978, Rainera Wernera Fassbindera; Markiza O, 'Die Marquise von O...', 1976, Erica Rohmera). Dzięki ograniczeniu wydatków oraz kredytów do minimum, New Line zapewniła sobie wypłacalność przez całe lata 70 .

Na początku lat 80. New Line wkroczyła na teren produkcji filmowej. Zwracając się w stronę młodszej publiczność, celując zwłaszcza w pary na randkach, firma postanowiła wykorzystać powracające do łask gatunki: horror i slasher, wykładając 2 miliony dolarów na realizację skromnego, odrzuconego przez inne wytwórnie filmu Koszmar z ulicy Wiązów (A Nightmare on Elm Street, 1984). Skupiony na postaci uzbrojonego w brzytwy Freddy'ego Kruegera obraz nie tylko zarobił w kinach 23 miliony dolarów, ale dał początek niezwykle popularnej serii, dzięki której New Line stała się najważniejszą firmą na rynku amerykańskiego kina niezależnego. Seria Koszmar z ulicy Wiązów zamknęła się ostatecznie w sześciu częściach ${ }^{* * * * *}$, które na całym świecie zarobily w sumie ponad 500 milionów dolarów ${ }^{27}$.

W roku 1986 New Line stała się spółką akcyjną z kapitałem zakładowym w wysokości 45 milionów dolarów. Nie zmieniło to jednak jej dotychczasowej strategii dystrybucyjnej. Firma nadal wypuszczała corocznie od dziesięciu do

25 L. Cohn, Oft Snubbed, Dubbed Euro Pix may Make a Comeback, „Variety” 1992, 10 August, s.72.

26 Niche was Nice: New Plan - Expand, „Variety” 1992, 10 August, s. 35, 44.

27 Ch. Mitchell, Schrewd Marketing Fuels Freddy, „Variety” 1992, 10 August, s. 36. 
dwunastu filmów będących zarówno produkcjami wewnętrznymi, jak i nabytkami od innych producentów. W roku 1990 New Line trafiło na kolejną żyłę złota, podejmując się dystrybucji odrzuconego przez 20th Century Fox filmu Wojownicze żótwie ninja (Teenage Mutant Ninja Turtles). Film zakupiony został za 3 miliony dolarów, zarobił zaś 130 milionów. Jego premiera odbyła się jednocześnie w dwóch tysiącach kin, co sprawiło, iż miał on najlepsze otwarcie spośród wszystkich niezależnych filmów w całej historii amerykańskiego przemysłu filmowego. Druga część Wojowniczych żótwi ninja zarobiła 78 milionów dolarów ${ }^{28}$.

Za zyski uzyskane z dystrybucji serii Koszmar z ulicy wiazów oraz Wojownicze źótwie ninja, a także kolejnych kinowych hitów, czyli filmów Prywatka (House Party, 1990) i Prywatka 2 (House Party 2: The Pajama Jam, 1991), New Line założyła jednostkę kina domowego oraz oddział produkcji telewizyjnej, a także nabyla prawa do wydań wideo 600 filmów, składających się na filmotekę Nelson Entertainment. Oprócz tego, w roku 1990 Robert Shaye założył w Nowym Jorku Fine Line Features, którego prowadzeniem zajął się mistrz marketingu Ira Deutchman. Nowy oddział służyć miał produkcji oraz dystrybucji wysublimowanych i prowokacyjnych filmów dla dorosłych. W ciągu zaledwie dwóch lat działalności Fine Line Pictures udało się znaleźć niszę na zatłoczonym rynku kina artystycznego.

Pierwszy wielki kinowy hit Fine Line, Moje prywatne Idaho (My Own Private Idaho, 1991) Gusa Van Santa z Riverem Phoenixem i Keanu Reevesem w rolach głównych, stanowi doskonały przykład kina, jakie stanie się specjalnością firmy. Ta niezależna produkcja amerykańska posiadała liczne cechy, które sprzyjały jej finansowemu sukcesowi: hollywoodzkie gwiazdy grające bardziej dla przyjemności niż dla zysku, rozpoznawalnych aktorów drugoplanowych obsadzonych w rolach głównych, sprawdzonego reżysera-autora, a także niekonwencjonalną historię. W przeciwieństwie do Miramax, Fine Line nie uciekała się do marketingowych sztuczek, ale bazowała na konwencjonalnych i sprawdzonych metodach promocji. Spośród innych godnych uwagi filmów dystrybuowanych przez Fine Line wymienić należy: Gracza (The Player, 1992) oraz Na skróty (Short Cuts, 1993) Roberta Altmana, Noc na ziemi (Night on Earth, 1992) Jima Jarmuscha oraz Barcelonę (1994) Whita Stilmana. Główną atrakcją wszystkich tych filmów były gwiazdy pokroju Tima Robbinsa, Whoopi Goldberg, Winony Ryder oraz Andie McDowell. Decydując się od czasu do czasu na dystrybucję filmów zrealizowanych poza Stanami Zjednoczonymi, Fine Line (podobnie jak Miramax) sięgała po obrazy, które zdobyły nagrody na znanych festiwalach filmowych, bądź też spotkały się z przychylnym odbiorem krytyki. Firma szczególnie upodobała sobie kinematografię brytyjską, rozpowszechniając takie filmy jak Edward II (1992) Dereka Jarmana, Londyn mnie zabija (London Kills Me, 1992) Hanifa Kureishiego, Tam, gdzie nie chadzaja anioly (Where Angels Fear to Tread, 1992) Char-

28 B. Weinraub, New Line Cinema, „New York Times” 1994, 5 June, s. F4. 
lesa Sturridge’a oraz Nadzy (Naked, 1993) Mike’a Leigh. Choć Fine Line omijała rynek filmów obcojęzycznych, ostatecznie zdecydowała się na dystrybucję dwóch. W roku 1992 wprowadziła na ekrany włoski obraz Volere volare (1991) Maurizio Nichettiego ${ }^{* * * * * *}$, zaś dwa lata później kanadyjsko-francuską koprodukcję Léolo (1992) Jeana Claude’a Lauzona.

Ostatnia firma, która przetrwała lata 80. to Samuel Goldwyn Co. Kierowana przez syna Samuela Goldwyna, noszącego takie samo imię jak ojciec, była jedyną firmą dystrybucyjną na rynku kina niszowego, dążącą do pionowej integracji. Założono ją w roku $1980 \mathrm{w}$ celu rozpowszechniania klasycznych filmów składających się na filmotekę Samuela Goldwyna. Jednak bardzo szybko firma wkroczyła na rynek kina artystycznego, a zaraz potem zajęła się produkcją filmową i telewizyjną, działając przy okazji w sektorze kina domowego oraz syndykacji. $\mathrm{Na}$ koniec Samuel Goldwyn Jr. rozpoczął budowę własnej sieci kin. Dywersyfikacja miała być sposobem na stabilizację finansów spółki ${ }^{29}$.

$\mathrm{Z}$ reguły Goldwyn dystrybuował od ośmiu do dziesięciu filmów rocznie, proponując swym widzom mieszankę kina anglojęzycznego z Wielkiej Brytanii i Australii, obcojęzycznych obrazów europejskich, niezależnych produkcji amerykańskich, a także filmów animowanych i dokumentalnych. Firma wyrobiła sobie reputację specjalisty od kina brytyjskiego, prezentując Amerykanom filmy najważniejszych twórców z Wysp, którzy w latach 80. i 90 . szukali sposobu by stać się konkurencją dla komercyjnego kina hollywoodzkiego. Pierwszym brytyjskim filmem dystrybuowanym przez Goldwyna była Dziewczyna Gregory'ego (Gregory's Girl, 1982) Billa Forsytha, romantyczna komedia dla młodzieży wyprodukowana w Szkocji. Jak donosiło „Variety”, obraz posiadał „wystarczająco dużo świeżości i wyjątkowego uroku”, by stanowić antidotum na „wulgarne komedie amerykańskie o podobnej tematyce (poczynając od Pom Pom Girls, kończąc zaś na najnowszej produkcji Świntuch, 'Porky's')"30.

Inne trendy $\mathrm{w}$ ówczesnym kinie brytyjskim reprezentowały: Positek oracza (The Ploughman's Lunch, 1985) Richarda Eyre'a, zjadliwa satyra na Wielką Brytanię Margaret Thatcher w okresie wojny falklandzkiej, Sid i Nancy (1986) Alexa Coxa, film oparty na życiorysie punkowego muzyka Sida Viciousa, Nadstaw uszu (Prick Up Your Ears, 1987) Stephena Frearsa, adaptacja sztuki Joego Ortona Wędrowna trupa (The Playboys, 1992) Gilliesa MacKinnona, jeden z serii filmów eksploatujących irlandzką scenerię, a także Henryk V (1989) oraz Wiele hałasu o nic (Much Ado About Nothing, 1993) Kennetha Branagha, popularne adaptacje sztuk Szekspira wpisujące się w formułę kina dziedzictwa narodowego.

Obcojęzyczne filmy zagraniczne nie odgrywały większej roli w biznesie Goldwyna, który ograniczał się do dystrybucji jednego, dwóch tego typu obrazów

\footnotetext{
29 A. Harmetz, Sam Goldwyn's...

30 „Variety Film Reviews”, 26 May 1982.
} 
rocznie. Pośród nich znalazły się Madame Bovary (1991) Claude’a Chabrola; Dobre chęci (Den goda viljan, 1992), film, którego scenarzystą był Ingmar Bergman, zaś reżyserem Bille August (wcześniej jego Pele zwycięzca, 'Pelle erobreren', z roku 1987 zdobył Złotą Palmę w Cannes oraz Oscara dla najlepszego obrazu obcojęzycznego); a także dwa wielkie hity: 3 hommes et un couffin (1985) Coline Serreau oraz Przyjęcie weselne (Xi yan, 1993) Anga Lee. (Obraz Serreau, dystrybuowany w USA pod tytulem Three Men and the Cradle, stal się podstawą dla zrealizowanego przez Disneya filmu Trzej mężczyźni i dziecko, 'Three Men and a Baby', 1987, który w kinach zarobił 168 milionów dolarów i dał początek całej serii amerykańskich remakéów francuskich hitów).

Chociaż udział niezależnych filmów amerykańskich w corocznym programie Goldwyna był jeszcze mniejszy aniżeli filmów obcojęzycznych, firma odpowiadała za dystrybucję trzech najbardziej frapujących obrazów tego okresu: Inaczej niż $w$ raju (Strenger than Paradise, 1984) Jima Jarmusha, Dzikość serca (Wild at Heart, 1990) Davida Lyncha oraz Miasto nadziei (City of Hope, 1991) Johna Saylesa.

Goldwyn rozszerzył swą działalność na inne sektory dopiero wówczas, gdy zapewnił sobie stabilną pozycję na rynku dystrybucji filmowej. Nawet wtedy stronił jednak od ryzyka. Wchodząc na rynek kina domowego, w roku 1984 firma powiększyła swój katalog o brytyjskie filmy składające się na filmotekę Alexandra Kordy. Jej celem nie było jednak wydawanie filmów na własną rękę, ale współpraca z firmami o ugruntowanej pozycji na rynku wideo. Równie zachowawczą strategię przyjęto w zakresie produkcji filmowej, dostarczając finansowego wsparcia wyłącznie projektom z komercyjnym potencjałem. Pierwszą inwestycją był film Złota foka (The Golden Seal, 1983) Franka Zunigi, celujący w rynek kina familijnego, drugą Raz ugryziona (Once Bitten, 1985) Howarda Storma, przestylizowana parodia kina wampirycznego skierowana do młodzieży. Na obszarze produkcji telewizyjnej firma skoncentrowała się na rynku syndykacji, raczej unikając współzawodnictwa z wielkimi wytwórniami o czas antenowy czołowych sieci telewizyjnych. Ostatnim akordem ekspansywnej polityki Goldwyna był zakup sieci kin artystycznych Landmark Theatres, w której posiadaniu znajdowało się sto dwadzieścia pięć ekranów rozmieszczonych w Minneapolis oraz stanach Kalifornia i Waszyngton. Powód tego przejęcia był prosty: gdyby tylko wyprodukowane przez firmę filmy poniosły klęskę, zawsze mogłaby ona zrównoważyć swoje straty dochodami z eksploatacji kinowej hitów innych dystrybutorów.

\section{Ofensywa wielkich wytwórni hollywoodzkich}

Prężne działanie firm Miramax, Fine Line oraz Goldwyn skłoniło wielkie wytwórnie do ponownego wejścia na rynek kina artystycznego. Sony Pictures Entertainment, właściciel Columbia Pictures oraz Tristar Pictures, powołał do 
życia w roku 1992 wyspecjalizowaną jednostkę Sony Pictures Classics. Pragnąc stworzyć oddział dostarczający od czasu do czasu zysków z dystrybucji zagranicznych hitów filmowych, Sony po prostu wynajęło kierowników wykonawczych odpowiadających za uruchomienie nowojorskiej jednostki Orion Classics: Miachaela Barkera, Toma Bernarda oraz Marcię Bloom.

Bez zgody na produkcję, a jedynie z upoważnieniem na zakup filmów jeszcze przed ich realizacją, Sony Classics w czasie pierwszych miesięcy swego funkcjonowania nabyło Powrót do Howards End (Howards End, 1992), adaptację powieści E. M. Forstera autorstwa Ismaila Merchanta i Jamesa Ivory'ego. Dzięki dystrybucyjnemu zaangażowaniu Sony Classics w ciągu czterech miesięcy od premiery film zarobił ponad 10 milionów dolarów, by pod koniec roku, po tysiącu otwarć w różnych kinach, przynieść wplywy w wysokości 21,3 miliona dolarów. Pomimo iż obraz spotkał się z dużym uznaniem krytyków i widzów, Sonny Classics rozpowszechniało go bardzo powoli, by „wypalał się jak najdłużej, a nie rozbłysł i od razu zgasł niczym flara", jak określił to jeden z prezesów firmy, Tom Bernard. Miał przez to na myśli stopniowe poszerzanie obszaru dystrybucji filmu, tak by utrzymywać wydatki na najniższym poziomie, natomiast zainteresowanie widowni na najwyższym w oskarowym wyścigu w roku $1993^{31}$. Następnie Sony Classics nabyło filmy dwójki reżyserów, których wcześniejsze obrazy dystrybuował Orion Classics: Oliver, Oliver (1992) Agnieszki Holland oraz Opowieść o Qui Ju (Qui Ju da guan si, 1993) Zhanga Yimou.

Podążając za przykładem Sony, znajdująca się w posiadaniu Matsushita wytwórnia Universal Pictures wespół z holenderską firmą PolyGram założyła w roku 1992 kompanię Gramercy Pictures. W przeciwieństwie do nastawionego głównie na zakup obcojęzycznych oraz anglojęzycznych filmów niezależnych Sony Classics, Gramercy planowało wewnętrzną produkcję na rynek kina niszowego. Co ciekawe, firmie chodziło nie tylko o czerpanie zysków z przebojowych produkcji, ale także o opiekę i budowanie trwałych relacji z młodymi, utalentowanymi twórcami. Jak powiedział jeden z kierowników wykonawczych wytwórni Universal: „dzięki uruchomieniu Gramercy Universal zyskał możliwość budowania coraz lepszych relacji z twórcami kina dla koneserów (quality filmmakers), a także swobodę w promowaniu następcy Spike'a Lee z dala od nerwowej atmosfery studia, gdzie rządzi zasada »wóz albo przewóz«"32.

Pomimo inicjatyw Sony i Universalu, do prawdziwego wejścia Hollywood na rynek kina artystycznego doszło w roku 1993, gdy swój ruch wykonały Disney oraz Turner Broadcasting. To właśnie w tym roku Disney najpierw połączył się

31 L. Cohn, Majors are Relying on Indies in a Major Way, „Variety” 1992, 27 April, s. 3; W. Grimes, Different Rules...; J. E. Frook, Sony Unit's „Howard” Slow Rollout Pays Off, „Variety” 1993, 11 January, s. 16, 18.

32 R. Natale, Gramercy to Rescue to Smaller Pix, „Variety” 1992, 25 May, s. 5,7. 
z Merchant-Ivory, a następnie wykupił Miramax. Zdaniem Petera Barta z „Variety" strategia Disneya polegała na

wspieraniu różnorodności projektów. [...] Podczas gdy konkurencyjne firmy zajmujące się rozrywką powielają model Time Warner, dążąc, nawet za cenę zadłużenia, do tego, by stać się wielosektorowymi, nastawionymi zarówno na software, jak i hardware korporacjami, Disney ma aspiracje stać się największym na świcie producentem własności intelektualnej. Właśnie dlatego od roku 1994 studio przystępuje do realizacji niesamowitego planu rozpowszechniania sześćdziesięciu filmów rocznie ${ }^{33}$.

Producencko-reżyserski zespół Ismaila Merchanta oraz Jamesa Ivory’ego przez trzydzieści jeden lat swej działalności zrealizował tyleż filmów. Spośród nich na wymienienie zasługuje przełomowa dla firmy adaptacja prozy Forstera Pokój $z$ widokiem (A Room with a View, 1986), która kosztowała 3 miliony dolarów, zaś na całym świecie zarobiła 68 milionów, a także film Powrót do Howards End, którego koszt równy był 8 milionom dolarów, podczas gdy ogólnoświatowe wplywy wyniosły 70 milionów dolarów. Umowa pomiędzy Disneyem a Marchant-Ivory zakładała trzyletni okres próbny. W jego trakcie Disney zobowiązał się między innymi pokrywać połowę budżetu każdego filmu realizowanego przez spółkę Marchant-Ivory, którego koszt produkcji nie przekraczał 12 milionów dolarów. W zamian za to miał otrzymywać wyłączne prawa do dystrybucji obrazu na terenie Stanów Zjednoczonych. Producencko-reżyserski zespół czerpał z powyższego układu podwójne korzyści: uwolniony został od konieczności poszukiwania na swoje projekty dużej części pieniędzy, a także zyskał wsparcie ze strony niezwykle skutecznego oddziału dystrybucyjnego Buena Vista Pictures. Z kolei wytwórni Disneya umowa dawała gwarancję stałego zaopatrzenia w wymagające filmy dla dorosłych widzów, bez ponoszenia zbędnego ryzyka produkcyjnego ${ }^{34}$.

Umowa, w oparciu o którą doszło do przejęcia Miramax przez Disneya, opiewała na kwotę 90 milionów dolarów. W wyniku tej transakcji Disney wszedł w posiadanie filmoteki Miramax składającej się z 200 anglo- i obcojęzycznych filmów oraz zobowiązał się pokrywać koszty przygotowań, produkcji oraz marketingu filmów realizowanych przez Miramax. Chociaż bracia Weinsteinowie podpisali pięcioletni kontrakt, który czynił ich pracownikami Disneya, Miramax zachowało swą centralę w Nowym Jorku, funkcjonując na zasadzie całkowicie autonomicznego oddziału Buena Vista Pictures ${ }^{35}$. Po połączeniu z Disneyem Miramax w dalszym ciągu dominował na rynku kina niezależnego, między innymi July, s. B1.

33 P. Bart, Mouse Gears for Mass Prod'n, „Variety” 1993, 19 July, s.1, 5.

34 B. Weinraub, Disney Sings Up Merchant and Ivory, „New York Times” 1992, 27

35 C. Eller, J. E. Frook, Mikey Munches on Miramax, „Variety” 1993, 3 May, s. 1, 60, 66. 
dzięki zakupowi praw do dystrybucji wartego 35 milionów dolarów eposowego filmu Maty Budda (Little Buddha, 1994) Bernarda Bertollucciego oraz sfinansowaniu Pulp Fiction (1994) Quentina Tarantino. W ciągu pierwszego roku współpracy Miramax przyczynił się do powiększenia nie tylko portfolio Disneya, ale także jego publiczności, odpowiadając za 10 procent wszystkich wpływów Buena Vista Pictures. Miramax wygrał również w roku 1994 wyścig o nominacje do Oscara, uzyskując ich w sumie dwadzieścia dwie; dla porównania Disney liczyć mógł tylko na dziewięć.

Turner Broadcasting wszedł na rynek kina artystycznego tylnymi drzwiami, przejmując New Line Cinema oraz Castle Rock Entertainment, producenta wysokiej klasy filmów i programów telewizyjnych z siedzibą w Beverly Hills. Ted Turner, założyciel legendarnej stacji WTBS w Atlancie, a także właściciel jednej z największych filmotek w biznesie, stał się w latach 80 . głównym dostawcą treści audiowizualnych dla telewizji kablowych. Poszerzając za kwotę 700 milionów dolarów swe medialne imperium o New Line oraz Castle Rock, Turner pragnął wedrzeć się na szczyty Hollywood oraz stworzyć platformę dającą możliwość globalnej ekspansji w dziedzinie filmu. Przy finansowym wsparciu Turnera New Line dwukrotnie zwiększyło liczbę rozpowszechnianych przez siebie filmów, dochodząc do ponad tuzina premier rocznie, a także bardzo agresywnie zaczęło zabiegać o wielkie gwiazdy, starając się, jak to ujął Robert Shaye, tworzyć „projekty miłe szerokim rzeszom kinowych widzów"36.

\section{Podsumowanie}

Ponowne zaangażowanie Hollywood w rynek kina niszowego przyniosło dwojakie efekty. Choć firmy takie jak Sony, Universal, Disney czy Turner Broadcasting w latach 90 . chętnie otwierały swe marketingowo-dystrybucyjne podwoje dla mniejszych niezależnych producentów oraz filmowców z zagranicy, rynek uległ poważnemu ujednoliceniu. Jak donosiło „Variety”, w roku 1993 prawie jedna trzecia produkcji „niezależnych” (indie) wyszła spod skrzydeł dwóch graczy: New Line-Fine Line (własność Turnera) oraz Miramax (własność Disneya) ${ }^{37}$. W czerwcu 1995 roku Samuel Goldwyn Co., ostatnia prawdziwie niezależna firma filmowa w USA, ujawniła, iż w poprzednim roku zanotowała straty na poziomie 20 milionów dolarów. Pogrążona przez kredyt zaciągnięty na zakup Landmark Theateres w wysokości 62 milionów dolarów oraz całą serię porażek kosztownych filmów i produkcji telewizyjnych, firma wystawiona została na sprzedaż $\dot{ }^{38}$. W grudniu 1995 roku

36 D. Cox, Turner Dough Feeds New Line's Desire, „Variety” 1994, 25 April-9 May, s. 11.

${ }^{37}$ L. Klady, Studio Deals Spark Indie Identity Crisis, „Variety” 1993, 13 December, s. 1,91 .

${ }^{38}$ M. Peers, Goldwyn Caught in Crunch, „Variety” 1995, 19-25 June, s.11. 
Goldwyn stał się własnością Metromedia International Group, międzynarodowej korporacji telekomunikacyjnej należącej do milionera Johna W. Klugego, który w swych rękach dzierżył także ministudio Orion Pictures. Nie potrafiąc wykorzystać filmotek Goldwyna i Oriona na użytek własnej korporacji, Kluge następnie sprzedał obie firmy Metro Goldwyn Mayer w kwietniu 1997 roku za 573 miliony dolarów ${ }^{39}$. W międzyczasie, w listopadzie 1996 roku New Line i jej oddział kina artystycznego ogłosily straty na poziomie 19 milionów dolarów. Niedługo potem nowy właściciel obu firm, Time Warner, który we wrześniu 1995 roku przejął Turner Broadcasting za 7,4 miliarda dolarów, wystawił je na sprzedaż $\dot{z}^{40}$. Pozostaje pytanie, jak długo w warunkach tak bezwzględnej konkurencji kino artystyczne będzie w stanie zachować swój alternatywny charakter.

$\mathrm{Z}$ angielskiego przełożył Krzysztof Jajko

Przypisy tłumacza i redakcji

Przywołana w tym miejscu przez Tino Balio definicja kina artystycznego stanowi przedłużenie powszechnego w USA przekonania, że wytwory kultury wysokiej mogą pochodzić wylącznie zza granicy, w szczególności zaś z Europy. Na co zwraca uwagę Robert Sklar, uformowana w latach 50. publiczność kina artystycznego przez długie lata podzielała pogląd, iż utwory rodzime mają charakter stricte rozrywkowy i nie zasługują na uwagę. Sytuacja ta zmieniła się dopiero w okresie tzw. hollywoodzkiego renesansu, kiedy to swe pierwsze filmy realizować zaczęli tacy twórcy jak Arthur Penn czy Martin Scorseese. Zob. R. Sklar, Movie-Made America: A Cultural History of American Movies, Vintage Books: New York 1994, s. 292-294. Warto także zauważyć, iż aczkolwiek artykuł Tino Balio wskazuje na żywotność wśród Amerykanów przekonania o artystycznym charakterze filmów zagranicznych także w kolejnych dekadach, dzisiejszy rynek dystrybucji filmów obcojęzycznych nie sprowadza się li tylko do rozpowszechniania dzieł wielkich autorów zza Oceanu. Jak dowodzi Robert Marich, obecnie ogromny udział w rynku kina obcojęzycznego mają także filmy etniczne oraz filmy rozrywkowe. Zob. R. Marich, Marketing to Moviegoers: A Handbook of Strategies and Tactics, Southern Illinois University Press: Carbondale 2009, s. 275-292 (przyp. thum.).

* Mianem mini-major w Hollywood określa się firmę, która podobnie jak wielkie wytwórnie (majors) nieprzerwanie zajmuje się produkcją oraz dystrybucją filmów, ale jest przedsięwzięciem mniejszej skali i uzyskuje zdecydowanie niższe wpływy. I tak na przykład, przywołany przez Tino Balio, Orion Pictures przez całe lata 80. odnotowywał udzialy na rynku wahające się od 1 do 7 procent (wyjątek stanowił

39 Metromedia to Sell Film Units to MGM for \$573 Million, „New York Times” 1997, 29 April, s. C9.

40 D. Cox, New Line Sees Red, „Variety” 1996, 11-17 November, s. 1, 73. 
rok 1987, kiedy uzyskał dziesięcioprocentowy wynik). Dla porównania, w tym samym czasie Paramount corocznie osiągał ponad piętnastoprocentowy udział na rynku, trzy razy będąc jego liderem z wynikiem około 20 procent. Zob. S. Prince, A New Pot of Gold. Hollywood under the Electronic Rainbow, 1980-1989, University of California Press: Berkeley 2000, s.17-18, 41. Dzisiaj mianem mini-major określić można firmę Lionsgate, która w latach 2004-2011 odnotowywała udziały na rynku wahające się od 2 do 5 procent, a w roku 2012 osiągnęla nawet wynik na poziomie ponad 12 procent. Zob. dane udostępnione przez serwis internetowy Box Office Mojo w dziale Studio market Share (przyp. thum.).

*** Tino Balio posługuje się w tym miejscu określeniem speciality film. W języku polskim trudno o literalny odpowiednik tego wyrażenia, który oddawałby jego pierwotny sens, a zarazem spełniał wymogi poprawności językowej. Dlatego też zarówno tu, jak i w innych miejscach tekstu określenie speciality film tłumaczone jest jako „film niszowy”. Jak się wydaje, sformułowanie takie najlepiej oddaje sens angielskiego pierwowzoru. Określenie speciality film obejmuje bowiem swym zasięgiem oba fenomeny, których opisem zajmuje się w tym artykule Balio, a więc zarówno zagraniczny film artystyczny (art film), jak i amerykański film niezależny (independent American film). Cechą charakterystyczną stosowanych przy ich rozpowszechnianiu strategii dystrybucyjnych i marketingowych jest zaś nastawienie na starannie wyselekcjonowaną publiczność niszową. Na dodatek, o czym pisze także Tino Balio, eksploatacja tego typu filmów zdecydowanie odbiega od standardów masowej dystrybucji kina blockbusterowego i ogranicza się do otwarcia w co najwyżej stu kinach (przyp. tlum.).

**** Wszystkie polskie i oryginalne tytuly filmów wymienionych $w$ tym artykule w oparciu o serwis imdb (przyp. tłum.).

Artykuł został opublikowany w 1996 roku, a więc nie obejmuje kolejnych filmów o Freddym Kruegerze takich jak remake z 2010 roku i crossover Freddy kontra Jason (Freddy vs. Jason) z 2003 oraz zdaje się pomijać szóstą część - Freddy nie żyje: Koniec koszmaru (Freddy's Dead: The Final Nightmare, 1991) (przyp. red.). Film był współreżyserowany przez Guida Manulego (przyp. red.). 